\title{
CIRCUITO DO LIVRO EM MINAS GERAIS E SUA IMPLICAÇÃO NO PROJETO EDUCACIONAL REPUBLICANO
}

\author{
André Coura Rodrigues \\ Mestre pela Faculdade de Educação \\ da Universidade de São Paulo
}

\section{Resumo}

Este artigo é parte de resultados de pesquisas interessadas na investigação da constituição do campo pedagógico em Minas Gerais nos primeiros anos de vigência da Reforma João Pinheiro (1906-1911). Para tanto, elegemos o livro didático como objeto central de análise, evidenciando sua trajetória no estado e o papel desempenhado como importante elemento entre as estratégias de imposição de uma nova cultura escolar.

\section{Palavras-chave}

Livro didático • Reforma João Pinheiro • Minas Gerais.

Correspondência

Faculdade de Educação - Universidade de São Paulo

Avenida da Universidade, 308

São Paulo - São Paulo - Brasil

CEP 05508-040

E-mail: andrecrx@usp.br 


\title{
BOOK'S CIRCUIT IN MINAS GERAIS AND ITS IMPLICATION IN THE REPUBLICAN EDUCATION PROJECT
}

\author{
André Coura Rodrigues \\ Masters' degree in Faculdade de Educação \\ of Universidade de São Paulo
}

\begin{abstract}
This article is part of research results interested in investigating the constitution of the pedagogical field in the state of Minas Gerais in the first years of the School Reformation João Pinheiro (1906-1911). We chose the textbook as the central object of analysis, highlighting its history and trajectory as an important element in the strategies of imposition of a new school culture.
\end{abstract}

\section{Keywords}

Textbooks • João Pinheiro School Reformation • Minas Gerais.

\section{Contact}

Faculdade de Educação - Universidade de São Paulo

Avenida da Universidade, 308

São Paulo - São Paulo - Brazil

CEP 05508-040

E-mail: andrecrx@usp.br 


\section{Introdução}

Este artigo é resultado de pesquisa realizada entre os anos de 2006 e 2009, inicialmente no âmbito do Grupo de Estudos e Pesquisas em História da Educação da FaE/UFMG ${ }^{1}$ e posteriormente desenvolvido no Programa de Pós-Graduação da Faculdade de Educação da USP. ${ }^{2} \mathrm{O}$ texto aqui apresentado é um recorte dos resultados alcançados em pesquisa que investigou a história do livro didático no Estado de Minas Gerais, o ensino de História e suas implicações no cotidiano da escola primária nos primeiros anos de vigência da Reforma João Pinheiro, implantada no ano de 1906.

O trabalho no Grupo possibilitou o primeiro contato com as fontes, que foram fundamentais para a escolha e delimitação do objeto de pesquisa. Foi investigada e coletada rica documentação do acervo do Fundo da Secretaria do Interior do Arquivo Público Mineiro, composto por relatórios de inspetores do ensino, de diretores de grupos escolares, de professores, coleções de leis e decretos oficiais, inventários das escolas, ofícios de secretários do Interior e de presidentes de Estado da fase inicial do regime republicano. A busca pela documentação se estendeu à Hemeroteca Estadual de Minas Gerais, onde foi possível manusear periódicos oficiais, jornais e revistas publicados na época. Semelhantes registros foram reveladores de estratégias adotadas pelos sujeitos para dar visibilidade social às transformações sofridas pela educação pública na década de 1910 em Minas Gerais.

As discussões realizadas acerca da constituição da nova cultura escolar pretendida pela elite política mineira naquele período permitiram pensar suas intenções enquanto prescrições para a escola que se inaugurava. O problema que se colocou para a pesquisa e que está refletido neste artigo relaciona-se à tentativa de se entender essas novas instituições educativas a partir do redirecionamento do olhar para seu funcionamento interno. Interessa aqui, portanto, revelar a escola enquanto prática, não contemplando apenas as informações transmitidas pela documentação de caráter oficial. A cultura escolar constitui, assim, base conceitual, conforme enunciação de Dominique Juliá: ${ }^{3}$

1 Projeto integrado de pesquisa Escolarização, culturas e práticas escolares: investigação sobre a constituição do campo pedagógico em Minas Gerais (1750-1970). Financiado pelo CNPq e Fapemig.

2 Projeto temático Educação e memória: organização de acervos de livros didáticos. Biblioteca do Livro Didático. Banco de Dados Livres. Financiado pela Fapesp.

3 JULIA, Dominique. A cultura escolar como objeto histórico. Revista Brasileira de História da Educação. Campinas, nº 1, jan./jun. 2001, p. 15. 
(...) um conjunto de normas que definem saberes a ensinar e condutas a incorporar e um conjunto de práticas que permitem a transmissão desses saberes e a incorporação desses comportamentos, normas e práticas ordenadas de acordo com finalidades que podem variar segundo as épocas (finalidades religiosas, sociopolíticas ou simplesmente de socialização). Normas e práticas não podem ser analisadas sem que se leve em conta o corpo profissional dos agentes que são chamados a obedecer a essas normas.

Um meio de investigação que tem sido bastante utilizado nas últimas décadas e mostra bons resultados quando se tenta compreender a constituição da cultura escolar tem sido o estudo das disciplinas escolares, que colabora no exercício de redirecionamento do olhar para o interior das instituições:

(...) para evitar a ilusão de um total poder da escola, convém voltar ao funcionamento "interno" dela. Sem querer em nenhum momento negar as contribuições fornecidas pelas problemáticas da história do ensino, estas têm-se revelado demasiado "externalistas": ela limitou-se a uma história das ideias, na busca por origens e influências. (...) É de fato a história das disciplinas escolares, hoje em plena expansão, que procura preencher essa lacuna. Ela abre, em todo caso, para retomar uma metáfora aeronáutica, a "caixa preta" da escola, ao buscar compreender o que acontece nesse espaço particular. ${ }^{4}$

Entre as diversas possibilidades de abordagem oferecidas pela investigação histórica das disciplinas escolares, o estudo dos manuais didáticos recomendados para as escolas apresenta-se como um dos mais instigantes e produtivos. O livro escolar é um dispositivo pedagógico central do processo de escolarização, pois nele estão refletidos os entendimentos dominantes de cada época, relativos às mobilidades da aprendizagem e ao tipo de saberes e de comportamentos que se deseja promover.

Considerando-se essas dimensões do manual didático, é possível, por intermédio dele, interpretar métodos e práticas de ensino de determinado tempo e lugar. Segundo Bittencourt, ${ }^{5}$ o livro escolar, ao fazer parte da cultura da escola, não integra essa cultura de forma arbitrária. Ele é organizado, veiculado e utilizado com alguma intencionalidade, já que é portador de uma dimensão da cultura social mais ampla. Dessa forma, esse material é aqui eleito como instrumento privilegiado de análise sobre a mediação que a escola realiza entre a sociedade e os sujeitos escolares, o que significa interpretar parte de sua função social.

JULIA, Dominique. Idem, op. cit., p. 9-44.

5 BITTENCOURT, Circe M. Livro didático e saber escolar (1810-1910). Belo Horizonte: Autêntica Editora, 2008. 


\section{Minas Gerais e a Reforma João Pinheiro}

De acordo com discussões já realizadas por Luciano Mendes e Tarcísio Vago, o Estado de Minas Gerais apresentava-se em profunda crise econômica e política nos anos que se seguiram à instalação do regime republicano. Essa situação se materializava no cotidiano das cidades, podendo-se conferir nas ruas a condição de miséria e ignorância de grande parte da população, especialmente a mais desprovida de recursos. Tal constatação fortaleceu a certeza de líderes políticos e de intelectuais republicanos de que era preciso criar uma política para se alterar essa realidade. A educação passou a ser considerada, desde então, um meio estratégico para realizar essa transformação, um verdadeiro recurso civilizatório. A difusão do ensino tornou-se fundamental no processo de expansão e consolidação dos ideais divulgados pela elite republicana mineira, tal qual ocorreu anteriormente nos estados de São Paulo e Rio de Janeiro.

Dentre os principais problemas que precisavam ser solucionados na escola estava a ausência de um espaço construído especialmente para o ensino. Ao lado dessa preocupação, estavam também outras: a dificuldade de manter alunos de diferentes níveis de aprendizagem na mesma sala de aula; falta de controle do Estado sobre as escolas; falta de material didático; baixa frequência dos alunos.

Diante desse impasse, a preocupação com a construção ou adaptação de prédios apropriados à manutenção do ensino tornou-se central nas discussões dos agentes reformadores:

No ano de 1897, Henrique Augusto de Oliveira Diniz, Secretário dos Negócios do Interior (responsável pelas questões afeitas à instrução pública) do governo do Presidente Bias Fortes, mostrou-se preocupado em expandir a instrução pública por considerá-la essencial para a consolidação do regime republicano: "A República será verdadeiramente amada quando constituir-se em sentimento consciente do povo e a difusão desse sentimento fundamental só poderá ser generalizada e fortalecida pela instrução" (grifo no original). ${ }^{6}$

Outra evidência dessa preocupação pôde ser constatada na fala do presidente de Estado, Francisco Salles, antecessor de João Pinheiro, em "Mensagem" publicada no jornal Minas Gerais, periódico oficial do governo:

${ }^{6}$ FARIA FILHO, L. Mendes de \& VAGO, Tarcísio Mauro. A Reforma João Pinheiro e a modernidade pedagógica. In: FARIA FILHO, Luciano Mendes de, PEIXOTO, Ana Maria Casasanta (orgs.). Lições de Minas: 70 anos da Secretaria da Educação. Belo Horizonte: Secretaria de Estado da Educação de Minas Gerais, 2000, p. 34. 
Como já tive oportunidade de dizer-vos e confirmo neste momento, o ensino público primário é o serviço que na atualidade mais atenção e até mesmo sacrifício merece dos altos poderes do Estado, pelo influxo direto e decisivo que exerce na formação da sociedade. (...) A solução do problema está em fornecer elementos de estímulo ao professor que se distinguir no exercício do magistério; aumentar seus vencimentos; fiscalizar convenientemente o ensino; fornecer prédios regulares às escolas com o necessário mobiliário. ${ }^{7}$

Dessa forma, o estímulo crescente à melhoria nas estatísticas do número de crianças matriculadas tornou-se meta importante dos republicanos mineiros, pois a escolarização estava associada ao ideal civilizatório daquele período. Segundo afirma Luciano Mendes, a solução para isso poderia ser alcançada a partir da instituição da obrigatoriedade do ensino, mas não com o modelo de escola que existia até aquele momento. Modelo, esse, que deveria ser extinto, pois já passava a ser associado aos demais elementos pertencentes ao passado arcaico monarquista:

Ora, as escolas isoladas eram um texto que, quando lido pelos agentes e profissionais da educação e boa parte da população, evocavam uma realidade muito distante daquela projetada pelos "textos" urbanísticos. Por isso, não significavam um rascunho a ser aperfeiçoado, mas algo a ser substituído, apagado da cena das cidades e, ao mesmo tempo, algo produzido na memória como passado que fora (ou deveria ser) extirpado para dar lugar ao novo. ${ }^{8}$

Diante desse quadro, inspirados pelos eventos ocorridos em São Paulo por ocasião da implantação da Reforma Caetano de Campos, entre outros movimentos disseminados pelo país, os agentes envolvidos com a educação pública mineira (sobretudo o secretário do Interior Carvalho Britto, principal idealizador, e o presidente de Estado, João Pinheiro), através da Lei n 439, de 28 de setembro de 1906, lançaram mão das novas diretrizes que organizariam a escola mineira nas próximas décadas. Dentre as alterações sugeridas por esses sujeitos, destacaram-se: fazer da escola um espaço de formação intelectual e física; estabelecer a gratuidade e obrigatoriedade do ensino; promover a seriação das turmas; adoção de métodos simples, práticos e intuitivos; novos programas de ensino e condições de matrícula; novo calendário escolar; quantidade de alunos por professores; frequência mínima; penalidades e processos avaliativos; reclassificação do professorado em efetivos (normalistas), adjuntos e substitutos;

\footnotetext{
SALLES, Francisco Antônio de. Mensagem dirigida ao Congresso Mineiro. 1906. Universidade de Chicago. Disponível em: <http://wwwcrl-jukebox.uchicago.edu/bsd/bsd/u290/index.html>. Acesso em: dezembro de 2006. p 4.

8 FARIA FILHO, Luciano Mendes de. Dos pardieiros aos palácios: cultura escolar e urbana em Belo Horizonte na Primeira República. Passo Fundo: UPF, 2000. p 45.
} 
construção e apropriação de prédios específicos para o ensino; provimento de mobília e material didático adequado; regulamentação da inspeção escolar.

Uma análise dos trabalhos produzidos sobre a Reforma permitiu afirmar que ela trouxe para o universo escolar os princípios da recém-inaugurada República brasileira. Palavras como ordem, civilidade, progresso, racionalidade e cidadania, tão caras ao discurso republicano, permearam a fala dos agentes envolvidos com a educação no período:

As experiências escolares iniciais, alimentadas pela experiência urbana, motivarão o surgimento dos grupos escolares voltados para a instrução elementar, empreendimentos que em Minas Gerais resultam de iniciativas tomadas durante o governo de João Pinheiro (1906-1910). ${ }^{9}$

Em Minas Gerais, e mais propriamente na nova capital, a instalação dessa nova organização escolar acontece no governo de João Pinheiro através da reforma de 1906.

(...) aos grupos escolares seria dada a organização mais adaptada aos intuitos de sua instituição. Tais objetivos estarão relacionados à própria monumentalidade expressa na necessidade de um povo instruído e regenerado para a nova vida, senão para a mais nova cidade da República: Belo Horizonte. ${ }^{10}$

\section{Sobre o mesmo tema, Faria Filho afirma:}

O processo de racionalização pelo qual vinha passando o "sistema público de instrução primária”, que atingia desde a maior definição, divisão e controle dos espaços e tempos escolares, passando pela afirmação das classes e disciplinas escolares até atingir os processos e os métodos de ensino, significava, naquele momento, um movimento de expansão da abrangência da educação escolarizada, que passava a ocupar-se de tarefas cada vez mais amplas e complexas. A escola racionalizava-se justamente porque tinha como finalidade última racionalizar o conjunto do social. ${ }^{11}$

Principal transformação introduzida pela Reforma, esse novo meio de organização da escola (os grupos escolares) sintetizou e materializou os anseios dos reformadores. Na documentação avaliada, não foi raro encontrar referências a esse evento como um momento oportuno para o rompimento com o passado mo-

9 VEIGA, Cynthia Greive. Cidadania e educação na trama da cidade: a construção de Belo Horizonte em fins do século XIX. Bragança Paulista: Edusf, 2002. p 234.

${ }^{10}$ VEIGA, Cynthia Greive. Estratégias discursivas para a educação em Minas Gerais no século XIX. In: VIDAL, Diana G. \& SOUZA, Maria C. C. C. (orgs.). A memória e a sombra - a escola brasileira entre o Império e a República. Belo Horizonte: Autêntica, 1999, p. 149.

${ }^{11}$ FARIA FILHO, Luciano Mendes de. Idem, op. cit., p. 177-178. 
narquista, simbolizado pela escola denominada isolada, que deveria ser abolida e substituída pelos grupos. A escola isolada se organizava a partir da reunião de um grupo de alunos em idades diferentes, com capacidades cognitivas diversas, em níveis de instrução também diferentes, em um mesmo espaço. Espaço esse geralmente impróprio para as atividades pedagógicas, conforme pôde ser observado nas críticas presentes nos relatórios de visitas de inspetores escolares. $\mathrm{O}$ inspetor escolar Estevam de Oliveira, ao retornar de sua viagem comissionada ao Rio de Janeiro e São Paulo, em 1902, manifestou seu deslumbramento com o andamento das questões relativas ao ensino primário em ambos os estados, e também seu desejo de ver similar transformação nas escolas mineiras:

Não devemos continuar a série de erros com a manutenção de muitas escolas singulares em um mesmo núcleo, cumpre-se mãos-à-obra e entrar-se no regime resoluto dos institutos primários de acumulação, denominados de grupos escolares. É esta instituição que há de reerguer o nosso ensino primário do estado de miséria a que se chegou. (...) A substituição gradativa da escola singular pela escola coletiva é o instrumento mais aperfeiçoado para o ensino integral. ${ }^{12}$

Portanto, a grande novidade estava na proposição de se construírem espaços próprios para a educação escolar. É a partir dessa mudança de lugar, físico e simbólico, que se tornou possível a construção de uma cultura escolar diferente em Minas Gerais e uma discussão específica sobre o conhecimento escolarizado: instituía-se uma nova cultura na escola, com tempo, espaço e métodos de ensino regulamentados, previamente definidos, buscando uma homogeneização tanto para os alunos quanto para os professores. A construção dos grupos escolares retrata a importância da nova escola pretendida, pois nela estaria a condição ideal para o desencadear de uma proposta pedagógica propiciadora de uma instrução pretensamente inovadora.

A partir da Lei $n^{\circ} 439$, que autorizou a reforma do ensino, surgiram os seguintes decretos, que regulamentavam a reforma: Decreto $n^{\circ} 1.947$, de 30/09/1906, que aprovou o programa de ensino; Decreto $\mathrm{n}^{\circ} 1.960$, de 16/12/1906, que aprovou o regulamento da instrução primária e normal; Decreto $n^{\circ} 1.969$, de 03/01/1907, que aprovou o regulamento interno dos grupos escolares e escolas isoladas; Decreto $n^{\circ} 1.982$, de 18/02/1907, que aprovou o regimento interno da escola normal da capital.

${ }^{12}$ OLIVEIRA, Estevam. Reforma de ensino público primário e normal em Minas. Belo Horizonte: Imprensa Oficial, 1902, p. 4. 


\section{0 programa de ensino da Reforma Joc̃o Pinheiro}

O novo programa de ensino aprovado pelo presidente de Estado João Pinheiro, através do Decreto $\mathrm{n}^{\circ} 1.947$, que vigorou a partir de 30 de setembro de 1906 e se estendeu até o ano de 1911, também foi responsável pela distribuição e ordenação dos quadros de horários para cada uma das disciplinas, bem como pela apresentação das instruções de abordagem dos conteúdos de cada um dos programas do currículo.

Irlen Gonçalves afirma, em sua pesquisa sobre a produção dos grupos escolares em Minas Gerais, quando discute a implementação do novo programa de ensino:

Agora, não apenas uma substituição ou uma reorganização de disciplinas e/ou conteúdos escolares, mas um novo modelo ou uma nova forma escolar se impunha. A nova organização do grupo escolar, que contou com uma concentração de crianças num mesmo prédio escolar, distribuídas em, pelo menos, quatro salas de aula, obedecendo à seriação e à hierarquização da aprendizagem e, ainda, sob a orientação de um novo método de ensino, demandou uma reestruturação do programa para atender aos novos objetivos do ensino primário. ${ }^{13}$

Esse tipo de inovação proposto pela reforma de 1906 estava de acordo com as transformações ocorridas nas nações modernas, defendidas pelos políticos e intelectuais da época. Nesses países, notadamente nos Estados Unidos (principal referência da elite republicana mineira), desenvolvia-se o modelo de escola graduada, com propostas de classificação homogênea para os alunos, dividindo-os em várias salas em um mesmo prédio, com vários professores, cada qual com suas respectivas turmas, onde o que se reforçava era uma proposta pedagógica voltada para o desenvolvimento das habilidades de observação. Rosa de Fátima Souza, ${ }^{14}$ ao analisar a origem dos grupos escolares no Brasil, chama atenção para o modelo pedagógico praticado em países como França, Espanha, Estados Unidos e Inglaterra e afirma a posição das propostas brasileiras no encalço dessas experiências.

O Decreto $n^{\circ} 1.947 / 1906$, que estabeleceu o programa de ensino, sugeriu as seguintes orientações: uma instrução para cada disciplina, visando orientar o professor sobre a aplicação de cada um dos conteúdos que deveria ser lecionado;

${ }^{13}$ GONÇALVES, Irlen Antônio. Cultura escolar: práticas e produção dos grupos escolares em Minas Gerais (1891-1918). Tese de doutorado. Faculdade de Educação da UFMG. Belo Horizonte, 2004 , p. 85.

${ }^{14}$ SOUZA, Rosa Fátima de. Espaço da educação e da civilização: origens dos grupos escolares no Brasil. In: SOUZA, Rosa Fátima de; VALDEMARIN, Vera Teresa; ALMEIDA, Jane Soares de. O legado educacional do século XIX. Araraquara: Unesp, 1998. 
seus respectivos conteúdos distribuídos para cada ano escolar; a organização do horário de funcionamento semanal de cada uma das matérias.

As disciplinas do ensino primário, estabelecidas pelo novo currículo, foram apresentadas da seguinte maneira: ${ }^{15}$

1. Leitura

2. Escrita

3. Língua Pátria

4. Aritmética

5. Geografia

6. História do Brasil

7. Instrução Moral e Cívica

8. Geometria e desenho

9. História Natural, Física e Higiene

10. Exercícios físicos

11. Trabalhos manuais

12. Música vocal

A distribuição dos horários ao longo da semana foi minuciosamente detalhada e pode ser conferida no quadro a seguir:

${ }^{15}$ MINAS GERAIS. Coleção das Leis e Decretos do Estado de Minas Gerais. Fundo da Secretaria do Interior do Arquivo Público Mineiro. Belo Horizonte: Imprensa Oficial do Estado, 1907, p. 62. 


\section{Horário do primeiro ano}

\begin{tabular}{|c|c|c|c|c|c|c|}
\hline Horas & Segunda & Terça & Quarta & Quinta & Sexta & Sábado \\
\hline $\begin{array}{c}10 \mathrm{~h} 00- \\
10 \mathrm{~h} 25\end{array}$ & $\begin{array}{l}\text { Leitura } \\
\text { Aritmética }\end{array}$ & $\begin{array}{l}\text { Leitura } \\
\text { Escrita }\end{array}$ & $\begin{array}{l}\text { Leitura } \\
\text { Aritmética }\end{array}$ & $\begin{array}{l}\text { Leitura } \\
\text { Aritmética }\end{array}$ & $\begin{array}{l}\text { Leitura } \\
\text { Aritmé- } \\
\text { tica }\end{array}$ & $\begin{array}{c}\text { Leitura } \\
\text { Aritmética }\end{array}$ \\
\hline $10 \mathrm{~h} 50$ & \multicolumn{6}{|c|}{ Canto } \\
\hline $\begin{array}{l}11 \mathrm{~h} 00- \\
11 \mathrm{~h} 25\end{array}$ & $\begin{array}{l}\text { Língua Pátria } \\
\text { Geografia }\end{array}$ & $\begin{array}{l}\text { Aritmética } \\
\text { Geografia }\end{array}$ & $\begin{array}{l}\text { Língua Pátria } \\
\text { Escrita }\end{array}$ & $\begin{array}{l}\text { Escrita } \\
\text { Geografia }\end{array}$ & $\begin{array}{c}\text { Língua } \\
\text { Pátria } \\
\text { Escrita }\end{array}$ & $\begin{array}{l}\text { Língua } \\
\text { Pátria } \\
\text { Escrita }\end{array}$ \\
\hline $11 \mathrm{~h} 50$ & \multicolumn{6}{|c|}{ Exercícios físicos } \\
\hline $\begin{array}{l}12 \mathrm{~h} 15- \\
12 \mathrm{~h} 40\end{array}$ & $\begin{array}{c}\text { História do } \\
\text { Brasil } \\
\text { Escrita }\end{array}$ & $\begin{array}{c}\text { História do } \\
\text { Brasil } \\
\text { Escrita }\end{array}$ & $\begin{array}{l}\text { I. Moral e } \\
\text { Cívica } \\
\text { Aritmética }\end{array}$ & $\begin{array}{c}\text { Aritmética } \\
\text { Língua } \\
\text { Pátria }\end{array}$ & $\begin{array}{c}\text { História } \\
\text { do Brasil } \\
\text { Aritmé- } \\
\text { tica }\end{array}$ & $\begin{array}{l}\text { Aritmética } \\
\text { Geografia }\end{array}$ \\
\hline $01 \mathrm{~h} 05$ & \multicolumn{6}{|c|}{ Canto } \\
\hline $\begin{array}{c}01 \mathrm{~h} 15- \\
02 \mathrm{~h} 00\end{array}$ & $\begin{array}{l}\text { Aritmética } \\
\text { Leitura }\end{array}$ & $\begin{array}{l}\text { Aritmética } \\
\text { Leitura }\end{array}$ & $\begin{array}{l}\text { Leituras } \\
\text { Trabalhos }\end{array}$ & $\begin{array}{l}\text { Leitura } \\
\text { Escrita }\end{array}$ & $\begin{array}{l}\text { H. Natu- } \\
\text { ral, Física } \\
\text { e Higiene } \\
\text { Leitura }\end{array}$ & $\begin{array}{l}\text { Leitura } \\
\text { Trabalhos }\end{array}$ \\
\hline
\end{tabular}

\section{Horário do segundo ano}

\begin{tabular}{|c|c|c|c|c|c|c|}
\hline Horas & Segunda & Terça & Quarta & Quinta & Sexta & Sábado \\
\hline $\begin{array}{l}10 \mathrm{~h} 00- \\
10 \mathrm{~h} 25\end{array}$ & $\begin{array}{l}\text { Leitura } \\
\text { Aritmética }\end{array}$ & $\begin{array}{l}\text { Leitura } \\
\text { Aritmética }\end{array}$ & $\begin{array}{l}\text { Leitura } \\
\text { Aritmética }\end{array}$ & $\begin{array}{l}\text { Leitura } \\
\text { Aritmética }\end{array}$ & $\begin{array}{l}\text { Leitura } \\
\text { Aritmética }\end{array}$ & $\begin{array}{l}\text { Leitura } \\
\text { Aritmética }\end{array}$ \\
\hline $10 \mathrm{~h} 50$ & \multicolumn{6}{|c|}{ Canto } \\
\hline $\begin{array}{l}11 \mathrm{~h} 00- \\
11 \mathrm{~h} 25\end{array}$ & $\begin{array}{c}\text { Língua } \\
\text { Pátria } \\
\text { Geografia }\end{array}$ & $\begin{array}{c}\text { Geografia } \\
\text { Escrita }\end{array}$ & $\begin{array}{c}\text { Língua } \\
\text { Pátria } \\
\text { Escrita }\end{array}$ & $\begin{array}{c}\text { Escrita } \\
\text { Geografia }\end{array}$ & $\begin{array}{c}\text { Língua Pátria } \\
\text { Escrita }\end{array}$ & $\begin{array}{l}\text { Língua Pátria } \\
\text { Escrita }\end{array}$ \\
\hline $11 \mathrm{~h} 50$ & \multicolumn{6}{|c|}{ Exercícios físicos } \\
\hline $\begin{array}{l}12 \mathrm{~h} 15- \\
12 \mathrm{~h} 40\end{array}$ & $\begin{array}{c}\text { História do } \\
\text { Brasil } \\
\text { Escrita }\end{array}$ & $\begin{array}{c}\text { Língua } \\
\text { Pátria } \\
\text { Aritmética }\end{array}$ & $\begin{array}{l}\text { I. Moral e } \\
\text { Cívica } \\
\text { Aritmética }\end{array}$ & $\begin{array}{l}\text { Aritmética } \\
\text { Língua Pátria }\end{array}$ & $\begin{array}{l}\text { História do } \\
\text { Brasil } \\
\text { Aritmética }\end{array}$ & $\begin{array}{l}\text { Aritmética } \\
\text { Geografia }\end{array}$ \\
\hline $01 \mathrm{~h} 05$ & \multicolumn{6}{|c|}{ Canto } \\
\hline $\begin{array}{l}01 \mathrm{~h} 15- \\
02 \mathrm{~h} 00\end{array}$ & $\begin{array}{l}\text { Aritmética } \\
\text { Leitura }\end{array}$ & $\begin{array}{l}\text { Leituras } \\
\text { Trabalhos }\end{array}$ & $\begin{array}{l}\text { Leituras } \\
\text { Trabalhos }\end{array}$ & $\begin{array}{l}\text { Leituras } \\
\text { Trabalhos }\end{array}$ & $\begin{array}{l}\text { H. Natural, } \\
\text { Física e } \\
\text { Higiene } \\
\text { Leitura }\end{array}$ & $\begin{array}{l}\text { Leitura } \\
\text { Trabalhos }\end{array}$ \\
\hline
\end{tabular}


André Coura RODRIGUES. Circuito do livro em Minas Gerais e sua implicação no projeto educacional republicano.

\section{Horário do terceiro ano}

\begin{tabular}{|c|c|c|c|c|c|c|}
\hline Horas & Segunda & Terça & Quarta & Quinta & Sexta & Sábado \\
\hline $\begin{array}{l}10 \mathrm{~h} 00- \\
10 \mathrm{~h} 25\end{array}$ & $\begin{array}{c}\text { Leitura } \\
\text { Aritmética }\end{array}$ & $\begin{array}{l}\text { Aritmética } \\
\text { Escrita }\end{array}$ & $\begin{array}{c}\text { Leitura } \\
\text { Aritmética }\end{array}$ & $\begin{array}{l}\text { Leitura } \\
\text { Escrita }\end{array}$ & $\begin{array}{c}\text { Leitura } \\
\text { Aritmética }\end{array}$ & $\begin{array}{l}\text { Aritmética } \\
\text { Aritmética }\end{array}$ \\
\hline $10 \mathrm{~h} 50$ & \multicolumn{6}{|c|}{ Canto } \\
\hline $\begin{array}{l}11 \mathrm{~h} 00- \\
11 \mathrm{~h} 25\end{array}$ & $\begin{array}{l}\text { Geografia } \\
\text { História }\end{array}$ & $\begin{array}{c}\text { Geografia } \\
\text { História do } \\
\text { Brasil }\end{array}$ & $\begin{array}{l}\text { Língua } \\
\text { Pátria } \\
\text { História do } \\
\text { Brasil }\end{array}$ & $\begin{array}{c}\text { Geografia } \\
\text { História do } \\
\text { Brasil }\end{array}$ & $\begin{array}{c}\text { Língua } \\
\text { Pátria } \\
\text { H. Natural, } \\
\text { Física e } \\
\text { Higiene }\end{array}$ & $\begin{array}{c}\text { História do } \\
\text { Brasil } \\
\text { Escrita }\end{array}$ \\
\hline $11 \mathrm{~h} 50$ & \multicolumn{6}{|c|}{ Exercícios físicos } \\
\hline $\begin{array}{c}12 \mathrm{~h} 15- \\
12 \mathrm{~h} 40\end{array}$ & $\begin{array}{c}\text { Língua } \\
\text { Pátria } \\
\text { Geometria e } \\
\text { desenho }\end{array}$ & $\begin{array}{l}\text { Língua } \\
\text { Pátria } \\
\text { Aritmética }\end{array}$ & $\begin{array}{l}\text { I. Moral e } \\
\text { Cívica } \\
\text { Geometria } \\
\text { e desenho }\end{array}$ & $\begin{array}{l}\text { Aritmética } \\
\text { Língua Pátria }\end{array}$ & $\begin{array}{l}\text { História do } \\
\text { Brasil } \\
\text { Aritmética }\end{array}$ & $\begin{array}{c}\text { Geografia } \\
\text { Geometria e } \\
\text { desenho }\end{array}$ \\
\hline $01 \mathrm{~h} 05$ & \multicolumn{6}{|c|}{ Canto } \\
\hline $\begin{array}{c}01 \mathrm{~h} 15- \\
02 \mathrm{~h} 00\end{array}$ & Trabalhos & Trabalhos & Trabalhos & Trabalhos & Trabalhos & Trabalhos \\
\hline
\end{tabular}

\section{Horário do quarto ano}

\begin{tabular}{|c|c|c|c|c|c|c|}
\hline Horas & Segunda & Terça & Quarta & Quinta & Sexta & Sábado \\
\hline $\begin{array}{c}10 \mathrm{~h} 00- \\
10 \mathrm{~h} 25\end{array}$ & $\begin{array}{c}\text { Leitura } \\
\text { Aritmética }\end{array}$ & $\begin{array}{c}\text { Leitura } \\
\text { Aritmética }\end{array}$ & $\begin{array}{c}\text { Leitura } \\
\text { Aritmética }\end{array}$ & $\begin{array}{c}\text { Leitura } \\
\text { Aritmética }\end{array}$ & $\begin{array}{c}\text { Leitura } \\
\text { Aritmética }\end{array}$ & $\begin{array}{l}\text { Leitura } \\
\text { Aritmética }\end{array}$ \\
\hline $10 \mathrm{~h} 50$ & \multicolumn{6}{|c|}{ Canto } \\
\hline $\begin{array}{l}11 \mathrm{~h} 00- \\
11 \mathrm{~h} 25\end{array}$ & $\begin{array}{c}\text { Geografia } \\
\text { História }\end{array}$ & $\begin{array}{c}\text { Geografia } \\
\text { Língua } \\
\text { Pátria }\end{array}$ & $\begin{array}{c}\text { Geografia } \\
\text { História do } \\
\text { Brasil }\end{array}$ & $\begin{array}{c}\text { Geografia } \\
\text { História do } \\
\text { Brasil }\end{array}$ & $\begin{array}{l}\text { Língua } \\
\text { Pátria } \\
\text { Geografia }\end{array}$ & $\begin{array}{c}\text { História do } \\
\text { Brasil } \\
\text { Geografia }\end{array}$ \\
\hline $11 \mathrm{~h} 50$ & \multicolumn{6}{|c|}{ Exercícios físicos } \\
\hline $\begin{array}{c}12 \mathrm{~h} 15- \\
12 \mathrm{~h} 40\end{array}$ & $\begin{array}{l}\text { Língua } \\
\text { Pátria } \\
\text { Escrita }\end{array}$ & $\begin{array}{c}\text { Língua } \\
\text { Pátria } \\
\text { História do } \\
\text { Brasil }\end{array}$ & $\begin{array}{c}\text { Língua } \\
\text { Pátria } \\
\text { Geometria e } \\
\text { desenho }\end{array}$ & $\begin{array}{l}\text { Língua Pátria } \\
\text { H. Natural, } \\
\text { Física e } \\
\text { Higiene }\end{array}$ & $\begin{array}{l}\text { Língua } \\
\text { Pátria } \\
\text { I. Moral e } \\
\text { Cívica }\end{array}$ & $\begin{array}{c}\text { Língua Pátria } \\
\text { Geometria e } \\
\text { desenho }\end{array}$ \\
\hline $01 \mathrm{~h} 05$ & \multicolumn{6}{|c|}{ Canto } \\
\hline $\begin{array}{c}01 \mathrm{~h} 15- \\
02 \mathrm{~h} 00\end{array}$ & Trabalhos & Trabalhos & Trabalhos & Trabalhos & Trabalhos & Trabalhos \\
\hline
\end{tabular}


Na intenção de controlar a conduta dos professores e consequentemente a dos alunos dentro da sala de aula, também foi produzido um conjunto de orientações específicas para a prática de cada uma dessas disciplinas. Para o caso da disciplina História do Brasil para o ensino público primário, ficou assim detalhado:

I- Dos fatos e coisas da nossa História deve-se fazer seleção do que for mais grandioso e importante, transmitindo a princípio em forma de anedota e depois em descrição e narração simples, por conversa com os alunos.

II- Poucas ideias, claramente expressas, tendo muito em vista familiarizar os meninos com os fatos históricos do país, apreciar o valor dos grandes homens e inspirar o sentimento da pátria. Somente no terceiro ano se permitirá a adoção de um pequeno compêndio. ${ }^{16}$

Esse tipo de orientação pedagógica, que sugeria como cada conteúdo deveria ser aplicado, tinha como objetivo uniformizar o ensino e, com isso, conforme afirma Irlen Gonçalves, alcançar a racionalização do trabalho pedagógico no estado. Talvez tenha sido essa a principal meta almejada pelo governo de Minas Gerais quando idealizou a Reforma.

Considerando que os grupos escolares foram criados em momento posterior à formulação do programa de ensino, é possível afirmar que este tenha sido a base para as demais mudanças. Todo o conjunto de transformações ocorridas por ocasião da Reforma (grupos escolares, programa de ensino, corpo docente, fiscalização, aluno, frequência) pôde ser considerado um instrumento eficaz na tentativa de atingir os ideais republicanos de uniformização. A fala do secretário do interior Carvalho Britto permite pensar sobre essas aspirações:

Com o Grupo se consegue a divisão do trabalho escolar, a fiscalização permanente, o estímulo dos professores, a execução uniforme do programa de ensino, a atração do aluno para a escola, a frequência assídua, o hábito das crianças viverem em sociedade, corrigindo-se, modificando-se, aperfeiçoando de modo que o ideal republicano da igualdade pode ser atingido naturalmente no trato de poucas gerações. ${ }^{17}$

No novo programa, o ensino primário foi dividido em quatro anos, e cada um deles foi novamente dividido em duas partes (dois semestres), cada qual com

${ }^{16}$ MINAS GERAIS. Programa do Ensino Público Primário no Estado de Minas Gerais. Fundo da Secretaria do Interior do Arquivo Público Mineiro. Belo Horizonte: Imprensa Oficial do Estado, 1906, p. 109.

${ }^{17}$ BRITTO, Manoel T. de Carvalho. Relatório apresentado ao presidente de Estado pelo secretário do Interior em 1907. Fundo da Secretaria do Interior do Arquivo Público Mineiro. Belo Horizonte: Imprensa Oficial do Estado, 1907. 
seus respectivos conteúdos e disciplinas, conforme pode ser observado no caso da disciplina denominada Escrita:

\section{Distribuição dos conteúdos escolares por ano e semestre, na matéria Escrita, no grupo escolar, em 1906}

\begin{tabular}{|c|c|c|c|c|}
\hline Ano & Primeiro ano & Segundo ano & Terceiro ano & Quarto ano \\
\hline $\begin{array}{l}\text { Ma- } \\
\text { téria }\end{array}$ & \multicolumn{4}{|c|}{ Escrita } \\
\hline 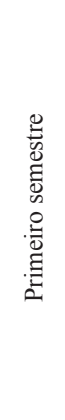 & $\begin{array}{l}\text { Cópia, a lápis ou } \\
\text { em ardósia, dos } \\
\text { modelos de linhas } \\
\text { e letras manuscritas } \\
\text { minúsculas, em } \\
\text { formato grande, } \\
\text { de estilo vertical } \\
\text { redondo. } \\
\text { Cópia, a lápis ou } \\
\text { em ardósia, dos } \\
\text { modelos de palavras } \\
\text { minúsculas, e em } \\
\text { formato menor. }\end{array}$ & $\begin{array}{l}\text { Cópia de novos } \\
\text { modelos, em tipo } \\
\text { comum, sempre } \\
\text { vertical redonda. }\end{array}$ & $\begin{array}{c}\text { Cópia de trechos de } \\
\text { livro de leitura, em } \\
\text { letra vertical redonda, } \\
\text { com a maior presteza } \\
\text { possível. }\end{array}$ & $\begin{array}{c}\text { Exercícios nos } \\
\text { mesmos cadernos, } \\
\text { preferindo o ditado. } \\
\text { Exercícios de letras } \\
\text { grandes para títulos } \\
\text { e cabeçalhos, rótulos } \\
\text { etc. }\end{array}$ \\
\hline 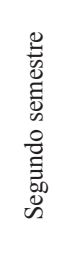 & $\begin{array}{l}\text { Cópia, a tinta, dos } \\
\text { modelos, em cader- } \\
\text { nos especiais. } \\
\text { Exercícios de letras } \\
\text { minúsculas. } \\
\text { Escrita de vocábu- } \\
\text { los fáceis, por } \\
\text { ditado. }\end{array}$ & $\begin{array}{c}\text { Cópia de trechos } \\
\text { de livros, em tipo } \\
\text { comum. }\end{array}$ & $\begin{array}{c}\text { Continuação dos mes- } \\
\text { mos exercícios. } \\
\text { Escrever lentamente } \\
\text { por ditado. } \\
\text { Cópia imitando tra- } \\
\text { balhos caligráficos. }\end{array}$ & $\begin{array}{c}\text { Continuação dos } \\
\text { mesmos exercícios, } \\
\text { adotando-se modelos } \\
\text { de letras de fantasia } \\
\text { para serem copiadas e } \\
\text { imitadas. }\end{array}$ \\
\hline
\end{tabular}

Ainda de acordo com Irlen Gonçalves, a estrutura que organizou os conteúdos e as disciplinas se tornou mais complexa, pois já não era mais suficiente esboçar os conteúdos sem considerar outros aspectos importantes do novo modelo escolar proposto. Como a escolha do local apropriado para as aulas, a associação dos conteúdos à seriação dos alunos, uso de material pedagógico adequado à escolarização da criança na idade entendida como própria para o desenvolvimento de certos aprendizados e, por fim, a aplicação de um novo método de ensino necessário à nova organização curricular. 


\section{Repercussões da Reforma}

Na primeira "Mensagem" enviada ao Congresso Mineiro, no ano de 1907, o presidente de Estado João Pinheiro demonstrou franca satisfação com o sucesso da implantação da Reforma. Em certo momento, referiu-se às transformações como um espetáculo, especialmente no que dizia respeito aos sucessos alcançados com a aplicação do novo método intuitivo, o rigor da fiscalização do ensino e, principalmente, pela promissora instalação dos novos estabelecimentos escolares que estavam de acordo com as propostas racionalizadoras do ensino. Todos esses elementos, segundo palavras do próprio presidente, colaboravam para o aumento e manutenção do número de alunos matriculados nas escolas públicas estaduais:

Para a alma mineira, é extraordinário conforto o espetáculo que oferece o início desse ressurgimento, cujas glórias, mais ao próprio povo cabem que ao Governo, tendo compreendido rapidamente que o interesse visado era o da coletividade, vendo-se a matrícula nas escolas primárias rapidamente quase que duplicada (Mensagem enviada ao Congresso Mineiro pelo presidente de Estado João Pinheiro no ano de 1907, p 06).

Os entusiasmos com andamento da instrução pública eram generalizados e podiam ser observados a todo instante, não somente pela elite política republicana estadual, mas também nas manifestações positivas dos demais sujeitos envolvidos no cotidiano das escolas, como professores, diretores, inspetores e mesmo os pais de alunos.

Tais expectativas não estavam destituídas de reais motivações, como pode ser percebido nas estatísticas produzidas pelo censo escolar de 1907. Segundo o relatório do secretário do Interior Carvalho Britto, apresentado ao presidente de Estado no final daquele ano, o número de alunos havia se elevado para 96.827, ultrapassando a marca até então inédita do governo de Afonso Penna, no início de 1892, que era de 73.457 alunos. ${ }^{18}$ Em relação à frequência, o mesmo relatório não apresentou nenhum dado estatístico. No entanto, o secretário afirmava ter "a convicção de que a frequência sob o novo regime escolar não teria cotejo na história". ${ }^{19}$

Cynthia Veiga, ao discutir as aproximações entre os projetos urbanos e os projetos escolares na produção de representações de educação no Brasil em fins do século XIX, sugere que as reformas escolares, realizadas em Minas Gerais a partir daquele período, pautavam-se pelo desejo de reinventar os sujeitos sociais,

\footnotetext{
${ }^{18}$ Sobre estatísticas escolares e produção da escola naquele período, ver o trabalho de MACHADO, Sandra Maria Caldeira (2008).

${ }^{19}$ Relatório apresentado ao presidente de Estado pelo secretário do Interior Carvalho Britto no ano de 1907, p. 23.
} 
sendo a escola afirmada como local legítimo de transmissão do saber considerado como necessário ao cidadão republicano. A escola é uma instituição social que emerge confrontando outras formas de socialização e de transmissão de saberes, as quais se viram relegadas e desqualificadas por sua instauração. A escola impõe às crianças uma oposição e ruptura com relação a seu espaço cotidiano de vida, "a sua forma habitual de estar, falar, mover-se e atuar". ${ }^{20}$

É evidente, no entanto, que esse processo de afirmação social da escola não ocorreu de forma harmônica e consensual, mas em meio a tensões estabelecidas com outras práticas culturais dos sujeitos. No caso de Minas Gerais, se as representações sobre a necessidade de civilizar a população pobre através da escola e inserir o estado no caminho da modernidade foram intensas, isso não significou que houve imediata adesão da população e harmonia entre as imposições prescritivas das normas e a vivência cotidiana das salas de aula.

Alguns estudos têm se debruçado sobre essa questão, na tentativa de revelar esse ponto de discordância. Entre esses trabalhos, considerando os que se interessam pelo período aqui abordado, merecem destaque os de Luciano Mendes, Carla Chamon, ${ }^{21}$ Irlen Gonçalves, Cynthia Veiga e Tracísio Vago. Em cada um desses trabalhos, fica evidente que a tentativa de configuração de uma nova cultura escolar em Belo Horizonte e demais regiões de Minas Gerais não ocorreu de forma consensual. Entre os sujeitos envolvidos com a tarefa de realizar as novas prescrições para o ensino primário (inspetores, secretários, diretores, professores) houve relações de adesão e obediência, mas também de resistência, revelando disputas de representações e conflitos de práticas que não se encaixavam no que estava previsto e determinado: pequenas alterações ou completa desobediência aos programas decretados, com o privilégio de determinadas disciplinas e marginalização de outras; alteração do tempo escolar; abandono da escola pelas crianças; pais se negando a enviar os filhos para as salas de aula. Esses são exemplos de dificuldades apontadas nos trabalhos citados e que podem ser evidenciados na documentação produzida pelos sujeitos:

${ }^{20}$ VEIGA, Cynthia Greive. Projetos urbanos e projetos escolares - aproximação na produção de representações de educação em fins do século XIX. Belo Horizonte: UFMG, Faculdade de Educação. 1997.

${ }^{21}$ CHAMON, Carla Simone. Maria Guilhermina Loureiro de Andrade: a trajetória profissional de uma educadora - 1869/1914. Tese de doutorado. Faculdade de Educação da UFMG. Belo Horizonte, 2005. 
Em todos os meus relatórios, desde o começo do meu exercício, como professora da escola isolada, eu me manifesto contra o horário das 10 às 14 horas, por não estar de acordo com os costumes mineiros em relação às horas da primeira refeição. ${ }^{22}$

\section{Livro didático: seu difícil percurso e as repercussões na Reforma}

Em Minas Gerais, no princípio do período republicano, mais especificamente em 1892, foi instituído o Conselho Superior de Instrução. Entre outras responsabilidades, era ele quem selecionava todo o material didático impresso que circulou (ou deveria ter circulado) no interior das salas de aula naquele momento. Seus membros deveriam avaliar, fazer revisões, sugerir alterações, adotar e/ou substituir os compêndios escolares, além dos programas de ensino e do material dos estabelecimentos públicos de ensino. As disposições legais que organizavam esse Conselho foram publicadas no Regulamento da Instrução Primária e Normal, aprovado pelo presidente de Estado João Pinheiro através do Decreto $n^{\circ} 1.960$, de 16 de dezembro de 1906. Os membros que compunham o corpo oficial desse órgão estavam, de formas variadas, relacionados à educação. Alguns figuravam no quadro de escolas, como diretores e professores. Outros eram nomeados pelo presidente de Estado de acordo com a participação na cena política. Alguns haviam servido também como inspetores escolares. A sede estava instalada na capital do Estado e funcionava sob a presidência do diretor da Secretaria do Interior, além de ter que acatar decisões do presidente de Estado. Além do diretor, seu corpo deveria ser composto por um inspetor escolar da capital, um diretor dos estabelecimentos de ensino secundário estadual, um professor da escola normal e um de escola primária de Belo Horizonte, além de um secretário designado pelo presidente. Todos eles deveriam possuir um suplente, escolhido por eles mesmos, e designado na ata da primeira sessão do Conselho. As atas eram publicadas em impressos oficiais do governo e as reuniões aconteciam no dia 10 de cada mês.

Outro documento que evidencia possíveis formas de resistência às transformações propostas para a escola pública é o relatório enviado à Secretaria do Interior pelo diretor do grupo escolar de Diamantina, prestando contas do funcionamento do estabelecimento de ensino. O diretor noticia a compra de livros didáticos que não estavam de acordo com a lista aprovada pelo Conselho Superior:

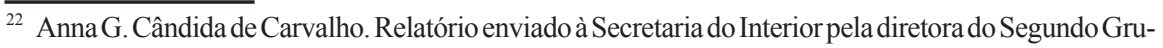
po Escolar da capital em 1910. Fundo da Secretaria do Interior do Arquivo Público Mineiro, 1910, p. 3. 
Mandei adotar, para uso dos professores, as Memórias do Distrito Diamantino, do Dr. Joaquim Felício dos Santos, obra rara e esplêndida, sobre a fundação do Tejuco (hoje Diamantina), origem do povoado, bandeirantes que o fundaram, primeiras famílias que aqui estabeleceram, lendas e anedotas célebres sobre os garimpeiros e os antigos contratadores de diamantes; etc. $^{23}$

Segundo Circe Bittencourt, ${ }^{24}$ o livro didático se inscreve na história do currículo no momento em que ocorre a construção do saber escolar e, portanto, se torna elemento fundamental no entendimento das prescrições realizadas para a educação em determinado contexto social. Dessa forma, considerando que o currículo constitui e é constituído como parte de projetos e de políticas educacionais mais abrangentes, a recusa pela indicação de determinada obra didática e a adoção de outra que estivesse em desacordo com as recomendações oficiais pode também ser entendida como uma forma de resistência ao modelo educacional proposto naquele momento para o Estado de Minas Gerais.

Ao se deparar com a crescente necessidade de fornecimento de material didático ao também crescente público escolar, o governo de Minas Gerais se viu obrigado a recorrer a diversas alternativas para satisfazer essa demanda. As iniciativas tomadas foram um tanto diferenciadas, o que colaborou para a configuração de uma multiplicidade de práticas por parte dos sujeitos responsáveis pela aquisição e distribuição de livros didáticos às escolas públicas primárias. As relações estabelecidas entre o poder público e a iniciativa privada eram bastante explicitadas pela atuação da editora Francisco Alves. Considerando que o livro didático foi um elemento fundamental no processo de aprendizagem das crianças do ensino primário, essa editora teve uma participação fundamental no processo de escolarização infantil no estado no período de instalação da Reforma João Pinheiro, sendo a principal fornecedora de livros e demais materiais didáticos ao governo nos primeiros anos da República.

Outras editoras também aparecem na documentação avaliada, sobretudo nas informações dos catálogos dos manuais encontrados. Além da citada Francisco Alves, também encontramos outras, responsáveis pelas publicações didáticas que circularam no Estado naquele período: Garnier; a Tipografia Americana, com sede no Rio de Janeiro; a Paes e Cia., de Belo Horizonte; Papelaria Mendes, do Rio de Janeiro; Imprensa Oficial do Estado de Minas Gerais; Cruz Coutinho,

${ }^{23}$ Cícero A. Caldeira. Relatório enviado à Secretaria do Interior pelo diretor do Grupo Escolar de Diamantina em 1907. Fundo da Secretaria do Interior do Arquivo Público Mineiro, 1907, p. 13.

${ }^{24}$ BITTENCOURT, Circe. Livro didático e saber escolar (1810-1910). Belo Horizonte: Autêntica Editora, 2008. 
de Portugal; Beltrão e Cia., de Ouro Preto; e Tipografia do Correio de Minas, de Juiz de Fora.

No entanto, a Francisco Alves, editora até então localizada na cidade do Rio de Janeiro, foi a única que manteve uma relação suficientemente sólida, intensa e próspera com o poder instituído, ao ponto de produzir vestígios que permitiram investigar trocas realizadas há um século. Além disso, o levantamento de informações e discussões sobre uma determinada editora talvez seja suficiente para se pensar todo o movimento realizado pelo governo com as demais empresas fornecedoras de livros, pois havia regras de procedimento que valiam para todas. E, independente das normas e da abertura de licitação (concorrência), independente de qual delas cumpria melhor os requisitos e vencia o pleito, o que realmente importava era a proposta mais conveniente para o Estado, fosse pela necessidade urgente de aquisição, fosse pela conveniência nos preços, pela facilidade do acesso, pela necessidade de se cumprir o programa de ensino, ou outra razão qualquer. Dessa forma, mesmo que a Francisco Alves vencesse todas as licitações (o que efetivamente aconteceu), o governo recorreu diversas vezes a outras empresas quando estas ofereciam condições mais favoráveis. Ou quando a necessidade de aquisição era urgente e não podia esperar a remessa da Francisco Alves vinda do Rio de Janeiro. Por outro lado, a citada editora foi diversas vezes acionada em ocasiões emergenciais, mesmo que outra empresa ou a Imprensa Oficial se disponibilizassem com melhores condições: apesar da distante localização, as reservas no depósito da Francisco Alves podiam ser uma alternativa mais eficaz para atender pedidos urgentes.

Ao realizarem pesquisas sobre a produção e a circulação de cartilhas e livros de leitura no Brasil entre os séculos XIX e XX, Francisca Maciel e Isabel Frade $^{25}$ realizaram interessante levantamento de informações a respeito das relações estabelecidas entre a editora Francisco Alves e o poder instituído de Minas Gerais. O trabalho realizado por elas e sua equipe do Ceale, ${ }^{26}$ aliada à documentação levantada para esta pesquisa, são as principais referências para se pensar essas relações.

Quando se intensificou a necessidade de aquisição de livros para o crescente número de alunos, a Francisco Alves se antecipou na oferta de material. Uma das estratégias utilizadas com frequência pela editora foi a doação de pequenas

\footnotetext{
${ }^{25}$ MACIEL, Francisca P. \& FRADE, Isabel C. A. S. Cartilhas escolares: ideários, práticas pedagógicas e editoriais. Minas Gerais/Mato Grosso/Rio Grande do Sul (1834-1996), 2003.

${ }^{26}$ Centro de Alfabetização, Leitura e Escrita da Faculdade de Educação/UFMG. Projeto temático Cartilhas produzidas e utilizadas no Brasil nos séculos XIXe XX. Financiado pela Fapemig e CNPq, 2003.
} 
quantidades às escolas mineiras. Essa estratégia, muitas vezes, foi suficiente para o convencimento das autoridades de que a editora apresentava, naquele momento, as melhores condições de provimento didático:

Pedimos a V. Ex. o especial obséquio de enviar-nos uma relação dos Grupos Escolares desse Estado, a fim de remetermos para a Biblioteca dos referidos Grupos uma coleção dos nossos livros didáticos, tendo já remetido a alguns diretores dos grupos escolares com quem temos relação, a fim de conhecerem desde já os livros didáticos editados pela nossa casa. ${ }^{27}$ Os senhores Francisco Alves e Comp., livreiros estabelecidos no Rio de Janeiro, ofereceram ao professorado do Estado livros didáticos, os quais foram aos mesmos distribuídos por esta Secretaria. ${ }^{28}$

Tem também o Governo fornecido grande quantidade de livros e outros materiais didáticos, relevando notar que os Srs. Francisco Alves e Comp. do Rio de Janeiro têm feito importantes donativos neste sentido. Além desses livros, outros, em pequenas quantidades, foram comprados para suprirem faltas ocorrentes. Os senhores Francisco Alves e Comp., livreiros estabelecidos no Rio de Janeiro, em cuja casa foi adquirida a maioria daqueles livros, também patrioticamente fizeram a distribuição gratuita de diversas obras a alguns dos Grupos Escolares. ${ }^{29}$

Tais estratégias evidenciam a aproximação entre a editora e o poder público, pois as dificuldades enfrentadas no envio de material didático para as escolas levaram os docentes a utilizarem os livros distribuídos pela Francisco Alves. E, na falta dos mesmos, diante do aumento das matrículas, esses profissionais solicitaram ao governo a remessa de mais volumes. Diante de tais pressões, o Conselho Superior aprovou determinados volumes que anteriormente não haviam sido autorizados.

A partir da primeira década do século XX, houve aumento considerável das trocas realizadas entre o governo e a editora fluminense. A documentação sobre essas trocas revelou um forte estreitamento na relação. Não podemos esquecer das dificuldades de transporte e comunicação enfrentadas naquele período, quando o uso das estradas de ferro e dos correios era bastante precário. Assim, há documentos que atestam a remessa direta de material didático do Rio de Janeiro para algumas escolas do interior do estado, sem passar pela supervisão

${ }^{27}$ Ofício enviado ao secretário do Interior pelo livreiro Francisco Alves, em novembro de 1909. Fundo da Secretaria do Interior do Arquivo Público Mineiro, 1909.

${ }^{28}$ Manoel T. de Carvalho Britto. Relatório enviado ao presidente de Estado pelo secretário do Interior no ano de 1907. Fundo da Secretaria do Interior do Arquivo Público Mineiro, 1907, p. 114.

${ }^{29}$ Estevão Pinto. Relatório enviado ao presidente de Estado pelo secretário do Interior em 1909. Fundo da Secretaria do Interior do Arquivo Público Mineiro, 1909, p. XXI e 325. 
da Secretaria do Interior. O diretor e/ou os professores desses estabelecimentos foram encarregados de conferir o material e relatar o estado em que chegavam a seus respectivos grupos escolares e escolas.

Outra estratégia utilizada pela Francisco Alves foi a promoção de livros que não estavam de acordo com a lista de autorizações publicada pelo Conselho Superior. Na documentação encontrada, há registro dessas ofertas, em momentos que a livraria tentava convencer o governo a adquirir obras similares às solicitadas quando estas estavam em falta ou não eram de propriedade da companhia:

Pelo correio sob registro remetemos a V. Ex. um exemplar do livro "Material Agrícola", que nos parece muito próprio para as escolas rurais e para as escolas técnicas de agricultura anexas às fazendas-modelo que o Governo desse Estado tão acertadamente tem fundado. No caso de V. Ex. pensar que este livro possa prestar o auxílio que julgamos, e queira adquirir exemplares, pedimos o obséquio de mandar dizer-nos a quantidade a fim de entrarmos em acordo com o respectivo editor, que se acha atualmente entre nós. ${ }^{30}$

De acordo com pesquisas realizadas por Kazumi Munakata, ${ }^{31}$ para se investigar a história das disciplinas escolares através do livro didático é preciso levar em consideração uma série de fatores que vão além da simples análise de seus conteúdos. Entre os outros elementos que o autor julga imprescindíveis, está o percurso desse material desde seu processo de fabricação até o momento que é utilizado nas salas de aula. Segundo o autor, ao longo desse caminho, o objeto livro experimenta diferentes situações que podem interferir no seu percurso e, por conseguinte, ocasionar alterações em todo o projeto educacional idealizado para determinada sociedade.

Conforme mostramos anteriormente, as relações entre editoras e poder instituído intensificaram-se, efetivamente, a partir dos primeiros anos do período republicano, especialmente por ocasião das reformas escolares ocorridas em fins do século XIX e primeiros anos do século XX. Os sujeitos envolvidos com os projetos reformistas, na intenção de realizarem o ideal de universalização do acesso à escola, se depararam com uma série de problemas que dificultavam o processo de atração e permanência das crianças nas salas de aula. Entre esses empecilhos estava a dificuldade de acesso à diversidade de materiais didáticos considerados essenciais no processo de aprendizagem. Os livros escolares assumiram grande

\footnotetext{
${ }^{30}$ Ofício enviado ao secretário do Interior de Minas pelo livreiro Francisco Alves em 21/07/1908. Fundo da Secretaria do Interior do Arquivo Público Mineiro.

${ }^{31}$ MUNAKATA, Kazumi. Produzindo livros didáticos e paradidáticos. Tese de doutorado em Educação. Pontifícia Universidade Católica. São Paulo, 1997.
} 
importância naquele momento, como instrumentos eficazes e indispensáveis desse processo. Diversos documentos produzidos por autoridades e profissionais do ensino atestam esse status do livro como elemento fundamental para a efetivação dos ideais reformistas, verdadeira peça-chave para o funcionamento de todo o aparato pretendido. Não são raros os documentos que registram essa realidade, que pode ser observada, sobretudo, nos pedidos de livros pelos diretores dos grupos e escolas isoladas e nos relatórios de inspetores:

Desejando que todos os alunos do Grupo começassem já a estudar os livros adotados para o segundo semestre do terceiro e segundo anos, tomo a liberdade de incomodar-vos novamente, rogando-vos o obséquio mandar-me os livros que há dias vos pedi para os alunos pobres. $^{32}$

(...) reconhecemos a impossibilidade absoluta de começarem imediatamente os trabalhos do Grupo, pelos seguintes motivos ponderados, que apresento ao esclarecido critério de V. Ex. (...) É também de grande necessidade que este estabelecimento seja dotado, com possível brevidade, de livros escolares adotados pelo Conselho Superior. (...) Enquanto não obtemos estes livros, resolvemos abrir uma matrícula provisória. ${ }^{33}$

(...) encontrei o primeiro ano da escola inteiramente desorganizado, em virtude das próprias condições materiais de precariedade que a suplantam. Basta dizer que os 18 alunos presentes do primeiro ano tinham livros diversos, cada um o seu, (...) porque cada aluno vai à escola com o livro que tem e o Estado não fornece material didático aos seus institutos primários, para se ter ideia precisa de como pode ser executado o programa de ensino de leitura simultânea. Em 25 minutos do horário há de o professor dar uma lição de leitura uniforme a 18 meninos, cada qual deles com um livro diverso. Não é, portanto, o titular da cadeira culpado por esta desorganização notada. ${ }^{34}$

Apesar da série de dificuldades encontradas na realização dos ideais da Reforma João Pinheiro, dos empecilhos surgidos pelo embate com outros hábitos culturais, é inegável que, a partir daquele ano, a população escolar aumentou consideravelmente em termos quantitativos, conforme foi demonstrado em momento anterior deste texto. Como consequência, as necessidades de acesso aos diversos materiais didáticos também aumentaram de forma considerável.

${ }^{32}$ Helena Penna. Ofício enviado ao secretário do Interior dr. Valadares Ribeiro pela diretora do Primeiro Grupo Escolar da capital em 26/07/1907. Fundo da Secretaria do Interior do Arquivo Público Mineiro, 1907.

${ }^{33}$ Cicero A. Caldeira. Ofício enviado ao secretário do Interior dr. Manoel Carvalho Britto pelo diretor do Grupo Escolar de Diamantina em 25/09/1907. Fundo da Secretaria do Interior do Arquivo Público Mineiro, 1907.

${ }^{34}$ Estevam Oliveira. Relatório de visita ao Grupo Escolar de São João Nepomuceno em 31/08/1907. Fundo da Secretaria do Interior do Arquivo Público Mineiro, 1907. 
O Estado, ao se deparar com essas novas necessidades, se viu obrigado a tomar iniciativas para prover os estabelecimentos educativos de material pedagógico considerado adequado para a realização dos ideais reformistas. O que se pôde observar a partir de então foi uma série de condutas diversificadas por parte das autoridades e dos profissionais da educação no sentido de sanar o problema.

No trecho do documento a seguir, podemos conferir um exemplo de como as autoridades agiram no processo de aquisição do material didático. A despeito das regras, das aprovações do Conselho Superior e da abertura de editais públicos para o fornecimento do material:

Tendo a Seção representado sobre a necessidade de se adquirirem alguns livros e objetos de que o depósito já sente falta, a fim de poderem ser atendidos vários pedidos aqui existentes, V. Ex. mandou consultar à Casa Alves e Cia., nesta Capital, sobre os preços. Respondeu à consulta a casa do Rio de Janeiro, naturalmente porque a daqui não tem o que se pediu. $\mathrm{O}$ orçamento, de acordo com os preços enviados, é o seguinte: (...) 10:810\$000. Cumpre-me dizer: que os "Exercícios de Linguagem" já foram fornecidos à Secretaria, pelo autor, a 900 réis o exemplar, e a Casa Alves os fornece a $1 \$ 400$. Não sei, porém, se o autor mantém o mesmo preço, nem se queria adquiri-los em mãos do mesmo. ${ }^{35}$

Logo abaixo, registro, do mesmo Durval Epaminondas, diretor da V Seção da Secretaria do Interior, órgão responsável pelo controle dos pedidos de material didático, bem como sua distribuição em todo o estado, a partir da cidade de Belo Horizonte, atestando recorrência à editora Francisco Alves em caráter emergencial:

Peço, pois, a V. Ex. se digne decidir sobre a aquisição dos livros constantes desta, a fim de que brevemente possam ser atendidas as requisições já existentes na seção. Se já tivesse ficado decidido quais os livros que o Conselho Superior julga deverem-se adotar nas escolas para o próximo ano, poder-se-ia levar a hasta pública o fornecimento: mas, devido à necessidade de aquisição mais rápida, convém comprá-los diretamente no Rio de Janeiro, na casa Alves \& Cia. ${ }^{36}$

Outro documento, do mesmo chefe da V Seção, mostra o descontentamento com a ineficiência do Conselho Superior e sobre a necessidade de se abrir concorrência pública devido à lentidão e altos preços da Imprensa Oficial:

${ }^{35}$ Durval Epaminondas. Ofício enviado ao secretário do Interior pelo chefe da V Seção em 05/06/1911. Fundo da Secretaria do Interior do Arquivo Público Mineiro, 1911.

${ }^{36}$ Durval Epaminondas. Ofício enviado ao secretário do Interior dr. Valadares Ribeiro pelo chefe da V Seção em 23/12/1911. Fundo da Secretaria do Interior do Arquivo Público Mineiro, 1911. 
Parece-me que o governo ainda não está aparelhado para fornecer aos estabelecimentos de ensino tudo quanto se contém nos artigos 187, 188, 190, 191, 192 e 195 do Regulamento 3191. Assim, especificarei aqueles que objetos que são de absoluta necessidade. (...) Em primeiro lugar vêm os livros, didáticos, de consultas e de escrituração. Os didáticos e os de consultas não sei quais sejam, porque a respeito nada resolveu ainda o Conselho Superior, nem sei se adotará essa ilustre corporação os mesmos livros que têm sido distribuídos ao professorado. (...) Os livros de escrituração, bem como impressos para mapas etc., devem também ser postos em hasta, em vez de comprados na Imprensa, que os fornece caro e com muita demora. ${ }^{37}$

A documentação encontrada também nos permitiu constatar a existência de relações diretas entre os autores e o poder público. Tal realidade reforçou a ideia de que houve grande diversidade de práticas nos processos de aquisição de material didático. Entre essas práticas, muitas vezes o que prevaleceu foi mesmo a conveniência em relação aos gastos públicos. Preocupação esta que influenciava até nas decisões do Conselho Superior no momento de escolha das obras, conforme observamos na troca de ofícios entre o autor de livros didáticos Carlos Ferreira Timões e o Estado:

Tendo organizado dois folhetos relativos ao ensino de História do Brasil e Geografia nos Grupos Escolares e escolas primárias, peço à V. Ex. para a Secretaria ficar com os mesmos para a distribuição pelo professorado. Os folhetos são intitulados - Pontos de História do Brasil pelo Dr. Ancil e Pontos de Geografia pelo Dr. Ancil - sendo o preço de 2\$000 para cada folheto. Desde, porém, que a Secretaria fique com número superior a dois mil folhetos de história e dois mil de geografia farei a redução e poderei aceitar a compra por $1 \$ 500$ e os darei por $1 \$ 000$ desde que o pedido seja de cinco mil folhetos para cada matéria. ${ }^{38}$

Em consequência, o chefe da V Seção, em documento enviado ao secretário do Interior, observou:

V. Ex. mandou, no despacho incluso, adquirir 1.000 a 1.500 exemplares dos Pontos de História e Pontos de Geografia, do Dr. Ancil. Para dar cumprimento ao mesmo despacho, consulto se devem ser adquiridos 1.000 de cada, pois os folhetos são dois; ou se deve comprar metade de um e metade de outro folheto. Pelo parecer do Conselho, aqui anexo,

${ }^{37}$ Durval Epaminondas. Oficio enviado ao secretário do Interior dr. Valadares Ribeiro pelo chefe da V Seção em 27/11/1911. Fundo da Secretaria do Interior do Arquivo Público Mineiro, 1911.

${ }^{38}$ Carlos F. Timões. Ofício enviado à Secretaria do Interior em 21/12/1911. Fundo da Secretaria do Interior do Arquivo Público Mineiro, 1911. 
verifico que só os Pontos de História do Brasil foram aprovados; mas, há professores que já têm pedido à Secretaria o folheto de geografia, sendo conveniente comprá-lo também. ${ }^{39}$

Alguns meses depois, as obras do autor foram aprovadas pelo Conselho Superior.

Como podemos perceber nos registros acima, havia uma diversidade de práticas referentes às primeiras etapas do circuito do livro no Estado de Minas Gerais à época de implantação da Reforma João Pinheiro. A despeito da existência de regras, materializadas em textos do Regulamento 3.191, que tentou organizar a compra e distribuição de toda diversidade de material didático para as escolas públicas, as pretensões da lei esbarravam em dificuldades de múltipla natureza. Diante de tais contratempos, os sujeitos envolvidos nos processos educativos encontravam soluções variadas na tentativa de sanar as necessidades mais urgentes. Um episódio curioso foi o do diretor do Grupo Escolar de Lavras, Firmino da Costa Pereira: uma nota fiscal atestou a compra de diversos materiais para seu grupo, inclusive livros didáticos, no seu próprio estabelecimento comercial, em 26/06/1907. O diretor mandava adquirir obras que não estavam de acordo com a aprovação do Conselho Superior, mas se encontravam disponíveis na sua Casa Comercial de Firmino da Costa Pereira, localizada na praça Municipal da cidade de Lavras. A loja do diretor da escola comercializava "fazendas, armarinho, chapéus, roupas feitas, calçados, ferragens, molhados, louças, papel, livros etc.”, conforme informações contidas na própria nota.

Segundo Circe Bittencourt, ${ }^{40}$ o livro didático é um objeto de difícil definição. Essa dificuldade se deve às suas diversas características, enquanto produto que sofre interferências de diferentes sujeitos ao longo de seu processo de produção, circulação e consumo. Portanto, ele possui ou pode assumir funções diferentes, dependendo das condições, do lugar e do momento em que é produzido, distribuído e utilizado.

Nos primeiros anos do século XX, em Minas Gerais, a condição de mercadoria assumida pelo livro didático se tornou cada vez mais evidente. Seu status de produto comercial o transformou em um objeto cobiçado e que necessitava de cuidados específicos. Suas funções pedagógicas, como elemento que compõe e participa de processos de aprendizagem, instrumento portador e divulgador de valores culturais interessantes para o poder instituído, passaram a dividir espaço

\footnotetext{
${ }^{39}$ Durval Epaminondas. Ofício enviado ao secretário do Interior pelo chefe da V Seção, em janeiro de 1912. Fundo da Secretaria do Interior do Arquivo Público Mineiro, 1912.

${ }^{40}$ BITTENCOURT, Circe. Ensino de história: fundamentos e métodos. São Paulo: Cortez, 2004.
} 
com outras características desse material: o livro didático como objeto de valor associado ao mundo editorial e à lógica da indústria cultural capitalista. Essa dimensão do livro provocou interferências no seu circuito pelo estado, conforme podemos constatar em alguns documentos encontrados no Fundo da Secretaria do Interior. Interferências essas que impossibilitaram seu devido uso, pois fizeram com que esse tipo de material talvez tivesse outros destinos que não fossem as salas de aula. O mesmo Durval Epaminondas, em ofício enviado ao secretário do Interior, fez a seguinte recomendação:

Acho de grande conveniência carimbarem-se todos os livros que a Secretaria fornece aos professores do Estado, a fim de se evitar que sejam vendidos ou trocados fora desta repartição; por isso peço a V. Ex. mandar a esta seção um dos carimbos usados aí no gabinete ou na Portaria, para que se possa fazer esse serviço. V. Ex. dirá se quer, no carimbo, fazer alguma recomendação ao professor. Lembrei-me de escrever esta: "O professor deve zelar pela conservação deste, impedindo que se perca, se extravie ou se estrague". É um carimbo para cadernos, livros e mapas. ${ }^{41}$

O documento acima sugere que os livros didáticos, bem como outros materiais pedagógicos destinados às escolas, assumiram a condição de objetos de elevado valor comercial, sendo necessário que o governo se mobilizasse para evitar perdas, desvios e demais usos indevidos, efetuados dentro da própria repartição pública.

Outro registro interessante encontrado entre os documentos do Fundo da Secretaria do Interior foi uma carta emitida pela professora Carolina Idalina Rosa, solicitando envio de livros didáticos e explicando a razão da falta dos mesmos em sua escola na cidade de Barbacena:

Comunico a V. Ex. que neste mês não pôde haver frequência legal, devido à epidemia de sarampo. Foram queimados 11 livros de primeira leitura de Artur Joviano, das alunas atacadas desse mal. Peço a V. Ex. se digne mandar remeter outros com urgência, pois elas estão agora estudando em livros imprestáveis, quase sem folhas. ${ }^{42}$

Em seguida, encontramos o comentário do chefe da V Seção também endereçado ao secretário do Interior:

${ }^{41}$ Durval Epaminondas. Ofício enviado ao Secretário do Interior pelo chefe da V Seção em 7/04/1911. Fundo da Secretaria do Interior do Arquivo Público Mineiro, 1911.

${ }^{42}$ Idalina Rosa. Ofício enviado à Secretaria do Interior em 2/08/1911. Fundo da Secretaria do Interior do Arquivo Público Mineiro, 1911. 
Podem ser fornecidos, em substituição, os livros de L. Gomes, porque ainda não há os de Artur Joviano. A V. Ex. deixo a apreciação do procedimento da professora queimando os livros que a secretaria lhe enviou. Quis cumprir à risca os conselhos que se contêm no folheto de Higiene Escolar, que a seção está distribuindo aos professores. Esse conselho, porém, permita-me V. Ex. dizê-lo, será de efeitos desastrosos para o Estado, se a moda pegar, pois não temos recursos suficientes para comprar livros caros e remetê-los aos professores para serem queimados. Não tenho a ousadia de querer entender do assunto, mas suponho que moléstias de crianças, nas localidades do interior, manifestam-se benignamente, não havendo necessidade de precauções tão severas porque elas não se propagam. $\mathrm{O}$ isolamento do docente, logo que se manifesta o mal, impediria sem dúvida o seu contágio. ${ }^{43}$

As determinações do Conselho Superior quanto ao material impresso que deveria circular nas salas encontravam obstáculos e muitas vezes não puderam ser obedecidas, seja pela necessidade urgente dos professores, seja pela conveniência em diminuir os gastos públicos, seja pelos extravios, seja pela dificuldade no envio das obras devido aos problemas com os Correios ou insuficiência no transporte ferroviário:

A remessa de livros e material didático é, na sua maior parte, efetuada pela Estrada de Ferro Central e os volumes despachados na estação da Capital, visto como grande quantidade de objetos não pode transitar pelo Correio. Acontece, porém, que, ultimamente, os obstáculos que os empregados da estação da Central opõem aos nossos despachos são tais, que eu, na impossibilidade de fazer despachos diários, venho reclamar de V. Ex. providências a respeito. Não sei por que motivo os volumes, enviados à estação, ficam dias e dias depositados e aqui, a seção, à espera dos respectivos conhecimentos, não pode dar andamento a todos os pedidos. Não quero falar nos maus tratos infligidos a empregados daqui que vão à estação levar material e lá são recebidos até com palavras obscenas pelos empregados da Central e, para evitar conflitos, suportam resignadamente o que estes querem lhes dizer. ${ }^{44}$

\section{Em defesa, a administração dos Correios informou:}

Acusando vosso ofício número 6 de 25/1/1911, cabe-me declarar-vos que a esta Repartição nenhuma responsabilidade cabe pela demora da entrega de correspondência a que aludis, visto como, tratando-se de correspondência cujo peso e volume são superiores aos que os carteiros são obrigados a conduzir, sempre a seção desta administração tem o cuidado de

${ }^{43}$ Durval Epaminondas. Ofício enviado ao secretário do Interior pelo chefe da V Seção em 11/08/1911. Fundo da Secretaria do Interior do Arquivo Público Mineiro, 1911.

${ }^{44}$ Durval Epaminondas. Ofício enviado ao secretário do Interior pelo chefe da V Seção em 25/01/1911. Fundo da Secretaria do Interior do Arquivo Público Mineiro, 1911. 
avisar às secretarias pra onde são destinadas a fim de que as mandem retirar. Quando há demora não recai a culpa disto sobre o correio, que expede aviso com toda prontidão. ${ }^{45}$

Como podemos perceber neste último documento, o ofício da Secretaria do Interior reclamando informações sobre o material didático enviado às cidades do interior do estado é datado de janeiro de 1911. A resposta da administração dos Correios é do mês de maio do mesmo ano. São cinco meses de intervalo entre os dois ofícios, o que confirma a permanência do material nos depósitos dos Correios todo esse tempo. Provavelmente as escolas para as quais o material havia sido endereçado não iniciaram as atividades devido ao atraso. Ou fizeram uso de material diferente daquele recomendado pelo governo, prática essa já observada em registros de outros documentos.

Portanto, o Conselho Superior se viu obrigado a voltar atrás em algumas decisões e reavaliar alguns pedidos de aprovação de livros didáticos. Como foi o caso dos folhetos citados acima, de Carlos Ferreira Timões, e também da obra Memórias do Distrito Diamantino, de Joaquim Felício dos Santos, adotada arbitrariamente pelo diretor do Grupo Escolar de Diamantina, devido à falta de outras obras, da impossibilidade de dar prosseguimento ao programa de ensino sem o uso de livros e pela demora do governo em cumprir a promessa de remeter manuais ao grupo. Motivos esses alegados pelo próprio diretor.

Nessas tentativas cotidianas de driblar as dificuldades e encontrar soluções muitas vezes paliativas e em desacordo com as normas, é evidente que o livro didático passou a ser considerado importante elemento para o funcionamento do aparelho educativo estadual, de acordo com os pressupostos da Reforma de 1906. As dificuldades para a aquisição de livros eram ainda mais prementes quando se tratavam de alunos mais carentes ou ainda pela ausência de livrarias nas cidades do interior do estado:

Peço a V. Ex. que queira ordenar que me sejam enviados alguns livros didáticos para uso dos meninos pobres. O maior embaraço que temos encontrado é a falta de livros. Os pobres não podem comprá-los, e até mesmo os que têm recursos, não os obtém com facilidade, porque é preciso encomendar do Rio de Janeiro. Não há livraria nesta cidade, nem os comerciantes têm relação comercial com os livreiros do Rio; de modo que as encomendas são feitas às casas de comércio, o que é motivo para ficarem os livros muito mais caros. ${ }^{46}$

\footnotetext{
${ }^{45}$ Carta da Administração dos Correios de Minas, enviado ao secretário do Interior em 6/05/1911. Fundo da Secretaria do Interior do Arquivo Público Mineiro, 1911.

${ }^{46}$ Amâncio G. Gurgel. Ofício enviado à Secretaria do Interior pelo professor Amâncio Gonçalves Gurgel em 12/05/1907. Fundo da Secretaria do Interior do Arquivo Público Mineiro, 1907.
} 
Há registros de casos em que a necessidade de aquisição dos manuais e dos demais materiais pedagógicos ia além dos limites das escolas, dos gabinetes da Secretaria do Interior e da preocupação de seus funcionários comissionados, provocando verdadeira alteração no cotidiano das cidades:

(...) consta-me que estimáveis cavalheiros e excelentíssimas famílias vão promover festas populares, corridas de ciclistas e outras diversões em benefício da caixa escolar do Grupo Escolar local. Muito louvável essa iniciativa, visto como a caixa escolar enfrenta não pequenos gastos com o fornecimento de vestuário e livros didáticos às crianças pobres matriculadas no grupo. ${ }^{47}$

Outra prática adotada para o fornecimento de livros aos alunos pobres foi a utilização da própria mão de obra gratuita de alunos das escolas técnicas. Em Ouro Preto, os alunos do Liceu de Artes e Ofícios tinham lições de encadernação e costura de livros. As aulas práticas de algumas disciplinas acabavam prestando serviços aos alunos pobres:

Na pequena oficina de encadernação, aplica-se especialmente, ao ensino de costura de livros, brochuras, dourado, e feitura de envelopes para ofícios e cartas. A oficina de encadernação tem prestado bons serviços. Na refundição de livros para meninos pobres e para o ensino. ${ }^{48}$

Em diversos registros como estes ficou evidente que os manuais didáticos eram considerados pelos profissionais da educação um material fundamental para o início, a continuidade e conclusão de todo o trabalho pretendido. Na falta deles, percebeu-se uma tendência ao estancamento das atividades nas salas de aula, comprometendo o andamento de toda a engrenagem educacional. Em alguns casos, o semestre letivo sequer se iniciava quando os pedidos de envio de livros não eram atendidos. O diretor do Grupo Escolar de Diamantina mais uma vez se pronunciou a esse respeito, anunciando mais um empecilho no percurso do material didático até seu estabelecimento de ensino:

Como já vos comuniquei por ofício, as aulas deste estabelecimento começaram a funcionar no dia 4 do corrente, apesar de não estarem ainda concluídas as obras da adaptação do prédio. (...) as aulas do Grupo Escolar não poderiam iniciar-se sem a chegada do material que despachastes para Curvelo, com destino a esta cidade. Ora, o referido material, segundo me

${ }^{47}$ Planalto de Minas. Periódico da cidade de Barbacena de 28/01/1909. Fundo da Secretaria do Interior do Arquivo Público Mineiro, 1909, p VII.

${ }^{48}$ Antônio Carlos Gregório. Ata dos exames do Liceu de Artes e Ofícios de Ouro Preto, realizados em novembro de 1909. Fundo da Secretaria do Interior do Arquivo Público Mineiro. 
consta, continua ainda na estação de Curvelo, por não terem querido os tropeiros carregar os volumes até esta cidade. Nestas condições, continuamos a lutar com alguma dificuldade, por falta de livros escolares e de escrituração e também por falta de mobília suficiente. ${ }^{49}$

Também o professor do Grupo Escolar de Lavras se pronunciou a respeito da importância da presença do objeto livro para a boa execução do programa de ensino:

Comunico-vos que recebi os livros didáticos vindos dessa Secretaria, cuja remessa eu vos agradeço. (...) Estou certo de que tais livros muito concorrerão para o bom andamento e eficácia do ensino nos grupos escolares, atento à utilidade de matéria neles contida e à boa orientação que sem dúvida hão de trazer aos professores ora empenhados em ministrar à mocidade mineira o ensino público primário. ${ }^{50}$

Conforme percebemos na documentação acima exposta, a distribuição dos livros didáticos no Estado de Minas Gerais não aconteceu de maneira uniforme e conforme o previsto pelas autoridades. Muitos foram os problemas enfrentados no percurso desse material, o que tornou seu circuito bastante imprevisível, desde a aprovação pelo Conselho Superior até seu uso nas escolas e grupos escolares do estado. Os livros aprovados pelo Conselho Superior não eram necessariamente adotados. Estes, por sua vez, não eram obrigatoriamente comprados. Mesmo os que eram adquiridos e distribuídos pelo governo muitas vezes não chegavam ao seu destino. Se chegavam, muitas vezes não eram usados. Se foram utilizados, não significa que chegaram às mãos dos alunos (a despeito de muitos deles serem remetidos para uso das crianças pobres, conforme regulamentação legal), se restringindo ao manuseio dos professores.

A ausência de uniformidade na distribuição do material didático às escolas públicas e o uso inadequado dos livros vieram se somar às demais dificuldades enfrentadas pelos agentes reformadores na tentativa de executar os seus ideais de homogeneização. Se outras dificuldades materiais produziram uma diferenciação entre as escolas isoladas e os grupos escolares, como o elevado número de alunos para as precárias instalações dos prédios, a realidade desses diferentes estabelecimentos se aproximava quando o assunto era falta de material didático. Evidentemente que a falta sentida refletia diretamente na qualidade pretendida para o ensino, especialmente no que diz respeito à imposição da disciplina:

${ }^{49}$ Cicero A. Caldeira. Relatório enviado à Secretaria do Interior pelo diretor do Grupo Escolar de Diamantina em 28/11/1907. Fundo da Secretaria do Interior do Arquivo Público Mineiro, 1907.

${ }^{50}$ Jacintho Pereira Almeida. Ofício enviado à Secretaria do Interior pelo professor do Grupo Escolar de Lavras em 14/09/1907. Fundo da Secretaria do Interior do Arquivo Público Mineiro, 1907. 
Dificulta muito à disciplina a falta de livros de leitura iguais e em número suficiente, bem como lousas, lápis, cadernos etc.; e como os meninos do Barro Preto são todos pobres e não levam nada, acho conveniente que o governo satisfaça com urgência o pedido da Diretora, ao menos neste período de organização. ${ }^{51}$

Conforme anunciado anteriormente, a adoção do método intuitivo foi uma das principais metas proclamadas pela elite republicana mineira durante os primeiros anos da Reforma. Assim como a construção dos grupos escolares, esse método figurou entre os principais elementos que compunham o discurso de modernização, elaborado pelos sujeitos envolvidos com a educação naquele período. A não adoção desse método tornou-se um dos grandes problemas para os profissionais da educação e diversos fatores colaboraram para que isso ocorresse. Entre os argumentos utilizados para justificar as falhas, o livro didático mais uma vez assume papel de relevância, pois a ausência desse material foi apontada como um dos principais empecilhos:

Aqui encontrei introduzido o prejudicialíssimo processo de ensino por meio de apostilas, as quais tratei de banir imediatamente. As lições de história, geografia, história natural, educação moral e cívica eram todas apostiladas e assim decoradas pelos alunos, de forma que, sem conhecimento seguro dos pontos, sem induções e deduções necessárias à interpretação deles, fazem provas escritas na aparência sofríveis. ${ }^{52}$

A diretora do Segundo Grupo Escolar da capital também se manifestou:

Também para que se torne uma realidade o ensino intuitivo pelos métodos modernos é indispensável material adequado a fim de que as mestras possam guiar as crianças na observação dos fatos e deles tirar os conhecimentos ao alcance de sua compreensão. ${ }^{53}$

Diante de tais evidências, podemos afirmar que o sucesso esperado pelos agentes reformadores do ensino dependia da realização de uma série de condutas pelos sujeitos que vivenciavam o cotidiano escolar naquele momento.

Quando se avalia o conjunto de relatórios de inspeção e os pedidos de materiais à Secretaria do Interior, percebemos que os livros assumiram grande importância no processo de renovação pedagógica pretendida pelo Estado. A

${ }^{51}$ Sebastião Corrêa Rabelo. Relatório de inspeção do Grupo Escolar do Barro Preto. Fundo da Secretaria do Interior do Arquivo Público Mineiro, 1911.

${ }^{52}$ Lindolpho Gomes. Relatório de inspeção do Grupo Escolar de Carangola em 11/11/1911. Fundo da Secretaria do Interior do Arquivo Público Mineiro, p 06.

${ }^{53}$ Maria G. Loureiro de Andrade. Relatório enviado à Secretaria do Interior pela diretora do Segundo Grupo Escolar da capital. Fundo da Secretaria do Interior do Arquivo Público Mineiro, 1911. 
André Coura RODRIGUES. Circuito do livro em Minas Gerais e sua implicação no projeto educacional republicano.

presença do livro didático e seu uso eficaz foram importantes componentes que precisavam ser acionados para, junto com demais prerrogativas, fazer funcionar toda a engrenagem da educação pública primária idealizada pelas autoridades republicanas mineiras.

Recebido: 31/05/2010 - Aprovado: 04/01/2011 